\title{
AN EXPERIMENTAL STUDY ON BIODISTRIBUTION OF DIACETYLMONOXIME IN SHEEP
}

\author{
A. K. SRIVASTAVA ${ }^{1}$, H. N. KHANIKOR ${ }^{2}$ and J. K. MALIK ${ }^{3}$
}

Department of Pharmalogogy, College of Veterinary Science ${ }^{1}$, Punjab Agricultural University, Ludhiana, Department of Pharmacology, Assam Agricultural University2, Gauhati, and Department of Pharmacology, Gujarat Agricultural University ${ }^{3}$, Anand, India

Received October 1, 1987

A b s $t$ r a c $t$

S r i $v$ a $t$ a $v$ a A. K., H. N. K ha n ikor, J. K. Ma $1 \mathrm{ik}$ : An Experimental Study on Biodistribution of Diacetylmonoxime in Sheep. Acta vet. Brno, 57, 1988: 13-18.

The distribution study of diacetylmonoxime (15 $\mathrm{mg} / \mathrm{kg}$, iv) in various body fluids and tissues of healthy sheep was conducted. In blood the therapeutic concentration $\geq 4 \mu \mathrm{g} \cdot \mathrm{ml}-1$ was maintained upto $8 \mathrm{~h}$. At different blood concentrations DAM penetrated into erythrocytes to the extent of 5.6 to 16.8 per cent. DAM was readily distributed in various body fluids and tissues. Highest concentration was recorded in brain $\left(7.51 \mu \mathrm{g} \cdot \mathrm{g}^{-1}\right)$ and lowest in liver $\left(2.25-4.49 \mu \mathrm{g} \cdot \mathrm{g}^{-1}\right)$. Approximately 16 per cent of the total dose of DAM was eliminated in urine of sheep during first $24 \mathrm{~h}$ of its administration.

Diacetylmonoxime, tissue distribution, urinary excretion, sheep.

of several phosphorylated acetylcholinesterase (EC 3.1.1.7) reactivators, diacetylmonoxime (DAM) has been reported to reactive acetylcholinesterase enzyme in central nervous system ( $T$ a y 1 o $r$ 1980). Recently DAM has been successfully employed in the treatment of domestic animals, severely poisoned with organophosphorus insecticides ( $\mathrm{E}$ c b $i \mathrm{c}$ h $\mathrm{n}$ 1976; M a 1 i k et el. 1984; $R$ a $i \mathrm{n}$ a 1984; $S \mathrm{r}$ i $\mathrm{v}$ a $t$ a $v$ et al. 1984). Clinical efficacy of acetylcholinesterase reactivators is completely dependent on their concentrations in central compartment and target tissues. Tissue distribution study of DAM and other reactivators has been investigated in man and experimental animals ( $u$ $1 \mathrm{t} z$ et al. 1957; $J$ a $g$ e $r$ et al. 1958; B a r k m a et al. 1963; $\mathrm{S} i \mathrm{~d}$ e 11 and $\mathrm{G}$ r o f $f$ 1971). The purpose of this communication is to report the distribution of DAM in various body tissues and fluids of sheep following single intravenous administration. 


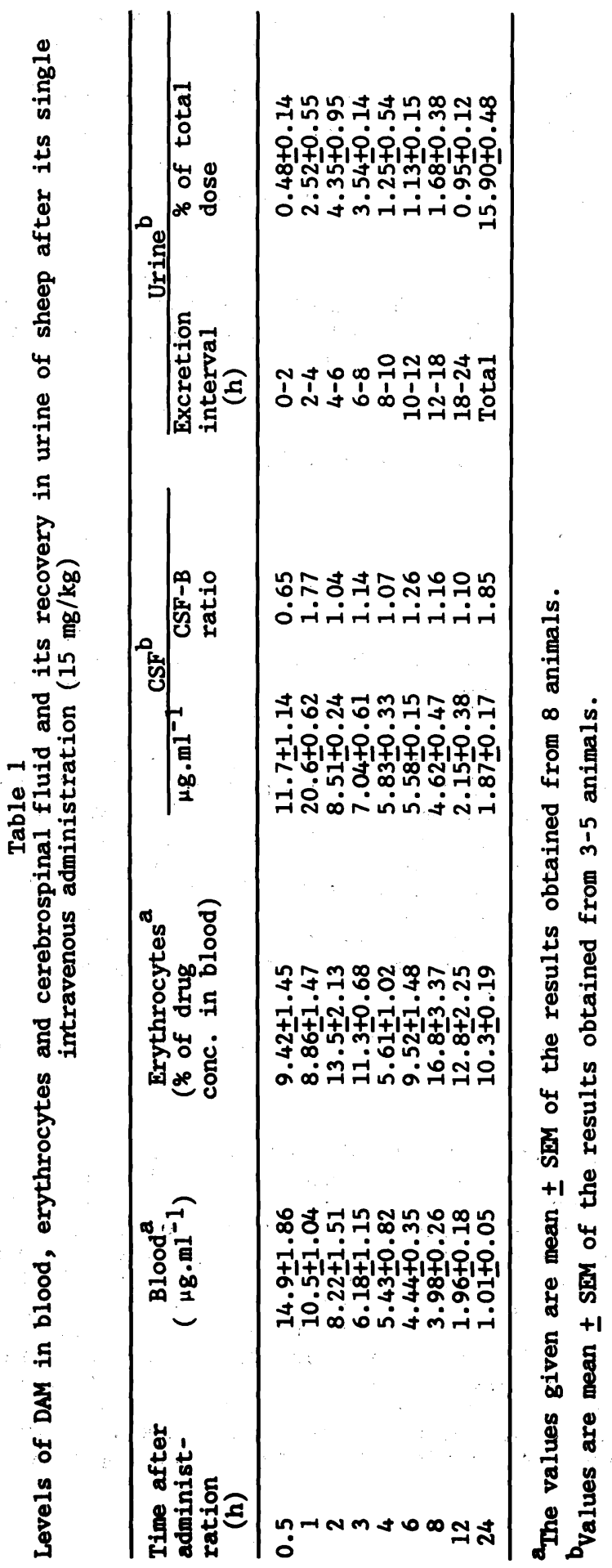


Materials and Methods

Animals and treatment

The study was performed on eighteen healthy sheep of both sexes (28-34 $\mathrm{kg}$ ). Before conducting the experiment, the animals were acclimatized for 10 days in the animal shed of department. After collecting the control blood sample, DAM (Aldrich Chemical Co. Milwaukee, Wisconsin) was administered in a single dose of $15 \mathrm{mg} / \mathrm{kg}$ body mass as freshly prepared $8 \%$ solution in sterile isotonic saline into the jugular vein of animals.

Collection of samples and analysis

An intravenous canula was placed in the opposite jugular vein through which blood was drawn. Blood samples were collected in heparinized test tubes at various pre-determined time intervals. Erythrocytes were separated at $3000 \mathrm{rpm}$ for 15 min at room temperature. CSF was collected from the lumbosacral joint of animal. For collecting urine, urinary bladder of three female sheep was catheterized by a Foley balloon catheter with the flexible metal probe. Urinary bladder was evacuated at 2, 4, 6, 8, 10, 12, 18 and $24 \mathrm{~h}$ after drug administration. For collection of tissues, animals were sacrificed at 15 and $180 \mathrm{~min}$ of injection and three to fifteen per cent (W/v) homogenate of each tissue sample was prepared in phosphate buffer (0.04 M; $\mathrm{pH} \mathrm{6),} \mathrm{using} \mathrm{a} \mathrm{Potter} \mathrm{Elvehjem} \mathrm{glass} \mathrm{homogenizer.}$

DAM was analysed in whole blood, erythrocytes, CSF, urine and tissue homogenates according to the procedure of $\mathrm{D} \mathrm{u} 1 \mathrm{t} \mathrm{z}$ et al. (1957).

\section{Results and Discus sion}

Table 1 represents the levels of DAM in blood, erythrocytes and CSF. The DAM concentration of $14.9 \pm 1.86 \mu \mathrm{g} \cdot \mathrm{ml}^{-1}$ of blood at $15 \mathrm{~min}$ gradually declined and at the end of $12 \mathrm{~h}$ traces of $1.96 \pm 0.18 \mu \mathrm{g} \cdot \mathrm{ml}^{-1}$ was recorded. The therapeutic blood level of oxime reactivators has been reported to be $\geq 4 \mathrm{\mu g} \cdot \mathrm{ml}^{-1}$ ( $\mathrm{S} \mathrm{i} \mathrm{d} \mathrm{e} 11$ and $\mathrm{G} \quad \mathrm{r}$ o f f $1971 ; \mathrm{sr}$ i $\mathrm{v}$ a s $\mathrm{t}$ a $\mathrm{v}$ a 1984). In this study this concentration of DAM was maintained from 15 to $480 \mathrm{~min}$ of its administration.

The effectiveness of acetylcholinesterase reactivators is certainly dependent on their penetration into erythrocytes, as organophosphorus insecticides are well known to inhibit the erythrocyte ChE to greater extent than other esterases ( $S \mathrm{r}$ i $\mathrm{v}$ a $\mathrm{s} t \mathrm{a}$ a et al. 1984). Accordingly, it was also thought of important to calculate the extent of penetration of DAM into erythrocytes. At different blood concentrations, DAM penetrates into erythrocytes to the extent of 5.6 to 16.8 per cent of total blood concentration. Any correlation between concentration of DAM in blood and extent of penetration into erythrocytes could not be established. Good penetration of DAM into erythrocytes reflects that DAM may be beneficial in the treatment of organophosphate insecticide (OPI) poisoning in sheep.

It is apparent from the data of Table 1 that build up of DAM in CSF was much faster than that of blood. At 15 min. 
the initial concentration of DAM in CSF

was

$11.7+1.14$

$\mu \mathrm{g} \cdot \mathrm{ml}^{-1}$ which gradually rose to peak $\left(20.6 \pm 0.62 \mu \mathrm{g} \cdot \mathrm{ml}^{-1}\right)$

at $60 \mathrm{~min}$. The concentration of DAM in $\mathrm{CSF}$ remained high as compared to blood up to $12 \mathrm{~h}$ and the CSF-blood ratio ranged from 0.65-1.85.

Table 2

Levels of DAM in body fluids and tissues of sheep at 15 and $180 \mathrm{~min}$ after a single intravenous dose of $15 \mathrm{mg} / \mathrm{kg}$ body mass

\begin{tabular}{|c|c|c|c|c|}
\hline \multirow[t]{3}{*}{$\overline{\text { Tissue/fluid }}$} & \multicolumn{4}{|c|}{ Time after DAM administration (min) } \\
\hline & \multicolumn{2}{|l|}{15} & \multicolumn{2}{|l|}{180} \\
\hline & $\mu \mathrm{g} \cdot \mathrm{g}^{-1}$ or $\mathrm{ml}^{-1}$ & $\mathrm{~T} / \mathrm{B}$ ratio & $\mu \mathrm{g} \cdot \mathrm{g}^{-1}$ or $\mathrm{ml}^{-1}$ & $\mathrm{~T} / \mathrm{B}$ ratio \\
\hline $\begin{array}{l}\text { Brain } \\
\text { Spinal cord } \\
\text { Liver } \\
\text { Kidney } \\
\text { Lung }\end{array}$ & $\begin{array}{l}46.4 \pm 4.32 \\
39.3 \pm 6.85 \\
4.49 \pm 0.32 \\
3.64 \pm 0.47 \\
5.33 \pm 1.12\end{array}$ & $\begin{array}{l}2.26 \\
1.92 \\
0.22 \\
2.94 \\
0.26\end{array}$ & $\begin{array}{l}7.51 \pm 1.15 \\
6.63 \pm 1.32 \\
2.25 \pm 0.35 \\
4.34 \pm 0.56 \\
8.38 \pm 0.93\end{array}$ & $\begin{array}{l}1.22 \\
1.07 \\
0.36 \\
0.70 \\
1.36\end{array}$ \\
\hline $\begin{array}{l}\text { Heart } \\
\text { Testes } \\
\text { Spleen } \\
\text { Muscle } \\
\text { Synovial fluid } \\
\text { Interstitial fluid }\end{array}$ & $\begin{array}{l}19.9 \pm 3.55 \\
11.8 \pm 2.62 \\
3.91 \pm 0.03 \\
17.1 \pm 1.65 \\
14.6 \pm 1.85 \\
40.9 \pm 6.94\end{array}$ & $\begin{array}{l}0.97 \\
0.58 \\
0.19 \\
0.83 \\
0.71 \\
1.99\end{array}$ & $\begin{array}{l}6.54 \pm 1.15 \\
7.81 \pm 0.39 \\
4.38 \pm 0.15 \\
14.3 \pm 2.68 \\
7.52 \pm 0.78 \\
13.6 \pm 2.73\end{array}$ & $\begin{array}{l}1.06 \\
1.26 \\
0.71 \\
2.31 \\
1.22 \\
2.20\end{array}$ \\
\hline
\end{tabular}

Values given are mean \pm SEM for 3 animals.

The results on distribution of DAM in different body tissues of sheep are summarized in Table 2. Of various body fluids and tissues, brain (7.51-46.4 $\left.\mathrm{\mu g} \cdot \mathrm{g}^{-1}\right)$ and spinal cord $\left(6.63-39.3 \mu \mathrm{g} \cdot \mathrm{g}^{-1}\right)$ accumulated highest concentration of DAM from 15-180 min of its administration. All organophosphorous insecticides produce their toxicity and lethality due to its effects on CNS mainly on the respiratory center in brain. Accordingly, it is essential that sufficient quantity of DAM inhibited cholinesterase enzyme in various parts of brain. The results of present findings are in agreement with previous studies suggesting that DAM readily penetrates $\mathrm{BBB}$ and reactivate brain $\mathrm{ChE}(\mathrm{W} i \mathrm{l} l \mathrm{~s}$ and $\mathrm{B}$ o $\mathrm{r}$ i s o n 1959; $\mathrm{B} \times \mathrm{r}$ o $\mathrm{n}$ 1960). In man also high concentration of DAM $\left(7-8 \mu \mathrm{g} \cdot \mathrm{ml}^{-1}\right)$ was estimated in central nervous system at 60 and $150 \mathrm{~min}$ of its intravenous administration 
( $\mathrm{J}$ a $\mathrm{g}$ e $\mathrm{r}$ et al. 1958). The minimum therapeutic concentration of DAM $\left(\geq 4 \mu \mathrm{g} \cdot \mathrm{ml}^{-1}\right)$ was maintained from 15-180 min in all tissues examined except kidney and liver. The relatively low concentration of DAM in kidney (3.6-4.3 $\mu \mathrm{g} \cdot \mathrm{g}^{-1}$ ) observed in the present study is in agreement with the findings of $\mathrm{D} u 1 \mathrm{t} z$ et al. (1957) and $J$ a $g$ e et al. (1958) who speculated that extra renal site is important for elimination of DAM from the animal body.

The above fact is further substantiated with results of renal excretion. Approximately 16 per cent of the total administered dose of DAM was eliminated in urine of sheep over a period of $24 \mathrm{~h}$ (Table 1). The maximum fraction i.e. 4.35 per cent of the dose was recovered within 4-6 h of injection of DAM. Studies conducted in healthy humans also revealed that urinary elimination of DAM is about 8 times lower than that of another enzyme reactivator 2-PAM ( $\mathrm{J}$ a $\mathrm{g} \mathrm{e} \mathrm{r}$ et al. 1958). The findings of the present investigation suggested that DAM can be effectively employed in the treatment of organophosphate insecticide poisoning in sheep.

Experimentální sledování biodistribuce diacetylmonoximu u ovcí

Distribuce diacetylmonoximu (DAM) v dávce $15 \mathrm{mg} \cdot \mathrm{kg}^{-1}$ při intravenózním podání byla sledována $v$ různých tělních tekutinách a tkáních zdravých ovcí. V jejich krvi byla terapeutická koncentrace $\geq 4 \mu \mathrm{g} \cdot \mathrm{ml}^{-1}$ udržena do $8 \mathrm{~h}$ po aplikaci. Pr̆i různých koncentracích $\mathrm{v}$ krvi DAM penetroval do erytrocytů $v$ rozsahu 5,6 až $16,8 \%$. DAM byl snadno distribuován do různých tělních tekutin a orgánů. Nejvyšší koncentrace byla nalezena $v$ mozku $\left(7,51-46,4 \mu \mathrm{g} \cdot \mathrm{g}^{-\mathrm{I}}\right)$ a nejnižší $v$ játrech $\left(2,25-4,49 \mu \mathrm{g} \cdot \mathrm{g}^{-1}\right)$ pokusných zvířat. Zhruba $16 \%$ celkové dávky DAM bylo eliminováno močí během prvních $24 \mathrm{~h}$ po aplikaci.

Эксперименталъное исследование биодистрибуции диацетилмонохима у овец

Дистрибуция

введенного

внутривенно исследована в разных 
здороьих овец. Терапевтическая концентрация в их крови $\geq 4$ мкг.мл ${ }^{-1}$ сохраниласъ до 8 часов после дачи. При разной концентрации в крови ДАМ пенетрировал в эритроциты в пределах 5,6 - $16,8 \%$. ДАМ легко распределялся в разные жидкости тела и органы. Самая болъшая концентрация была обнаружена в головном мозгу $\left(7,51-46,4\right.$ мкг. $\left.^{-1}\right)$ самая низкая - в печени $\left(2,25-4,49\right.$ мкг. $\left.\Gamma^{-1}\right)$ подопытных животных. В общем $16 \%$ обшей дозы ДАМ виделялосъ мочой в течение первых суток после введения.

\author{
Ref e rences
}

BARKMAN, R. - EDGREN, B. - SUNDEWALL, A.: Self administration of pralidoxime in nerve gas poisoning with a note on the stability of the drug. J. Pharm. Pharmacol., 15, 1963: 671-677.

BROWN, R. V.: The effects of intracisternal sarin and pyridine-2-aldoxime methyl methane- sulfonate in anaesthetized dogs. Br. J. Pharmacol., 15, 1960: 170-174.

DULTZ, L. - EPSTEIN, M. A. - FREDMAN, G. - GARY, E. H. - WELL, W. B.: Studies on a group of oximes as therapeutic compounds in sarin poisoning. J. Pharmaco1. Exp. Ther., 119, 1957: 522-531.

ECOBICHON, D. J.: Species differences in the reactivation of organophosphate inhibited plasma esterases by diacetylmonoxime. Can. J. Physiol. Pharmacol., 54, 1976: 86-93.

JAGER, B. V. - STAGG, G. N. - GREEN, N. - JAGER, L.: Studies on distribution and disappearance of pyridine-2-aldoxime methiodide (PAM) and of diacety1monoxime (DAM) in man and experimental animals. Bull. Johns. Hopkins. Hosp., 102, 1958: 225-234.

MALIK, J. K. - SRIVASTAVA, A. K. - PAUL, B. S.: Effects of 2,3-butanedione monoxime on fenitrothion induced acute toxicity and enzymic alterations in buffalo calves. Ind. J. Pharmac., 16, 1984: 59.

RAINA, R. K.: Toxicological and biochemical studies of 2,2-dichloro-vinyl dimethyl phosphate (dichlorvos) in Bubalus bubalis M.V.Sc. Thesis, Punjab Agricultural University, Ludhiana, 1984.

SIDELL, F. R. - GROFF, W. A.: Intramuscular and intravenous administration of small doses of 2-pyridinium aldoxime methochloride to man. J. Pharm. Sci., 60, 1971: 1224-1228.

SRIVASTAVA, A. K. - PAUL, B. S. - MALIK, J. K . : Comparative inhibiton of blood cholinesterases and carboxylesterase in buffalo calves intoxicated with fenitrothion. Ind. J. Pharmac., 16, 1984: 60 .

SRIVASTAVA, A. K.: Pharmacokinetics and Therapeutic evaluation of oxime reactivators in Bubalus bubalis. Ph.D. Thesis, Punjab Agricultural University, Ludhiana, 1984 .

TAYLOR, P.: Anticholinesterase agents. In: A. G. GILMAN, L. S. GOODMAN and A. GILMAN (Editors). The Pharmacological Basis of Therapeutics. Macmillan Pub. Co. Inc., New York, 1980: 100-119.

WILLS, J. H. - BORISON, H. L.: Modification by sarin and antagonists of medullary respiratory activities.Fed. Proc. 18, 1959: 459. 